\title{
Attaining the minimum target of resolution WHA 54.19 for schistosomiasis control in the Rainforest Zone of the state of Pernambuco, Northeastern Brazil
}

\author{
Tereza C Favre/+ , Ricardo AA Ximenes*, Aline F Galvão, Ana Paula B Pereira, \\ Tereza N Wandereley**, Constança S Barbosa***, Otávio S Pieri
}

\author{
Departamento de Biologia, Instituto Oswaldo Cruz-Fiocruz, Av. Brasil 4365, 21045-900 Rio de Janeiro, RJ, Brasil \\ *Departamento de Medicina Tropical, Universidade Federal de Pernambuco, Recife, PE, Brasil **Laboratório de Endemias, \\ Secretaria de Saúde de Pernambuco, Recife, PE, Brasil ***Departamento de Parasitologia, Instituto Aggeu Magalhães-Fiocruz, \\ Recife, PE, Brasil
}

Resolution 19 of the 54th World Health Assembly (WHA-54.19) urged member nations to promote preventive measures, ensure treatment and mobilize resources for control of schistosomiasis and soil-transmitted helminthiases (STH). The minimum target is to attend $75 \%$ of all school-age children at risk by year 2010. The Brazilian Ministry of Health $(\mathrm{MoH})$ recommends biennial surveys of whole communities and treatment of the positives through the Schistosomiasis Control Program within the Unified Health System (PCE-SUS). However, by 2004 the PCE-SUS had covered only $8.4 \%$ of the 1.2 million residents in the Rainforest Zone of Pernambuco (ZMP). Six of the 43 municipalities still remained unattended. Only three of the municipalities already surveyed reached coverage of $25 \%$ or more. At least 154 thousand children in the 7-14 years old range have to be examined (and treated if positive) within the next five years to attend the minimum target of the WHA 54.19 for the ZMP. To make this target feasible, it is suggested that from 2006 to 2010 the PCE-SUS actions should be complemented with school-based diagnosis and treatment, involving health and educational organs as well as community associations to include both children in schools and non-enrolled school-age children.

Key words: schistosomiasis - control - Pernambuco - Brazil

Schistosomiasis remains a serious public health problem both at the global (Engels et al. 2002) and national (Coura \& Amaral 2004) levels. As regards the endemic area of the state of Pernambuco, a number of studies have identified causal factors in the scope of bio-ecological, cultural, economic, demographic, and behavioural aspects (Barbosa \& Barbosa 1998, Freese de Carvalho et al. 1998, Moza et al. 1998, Ximenes et al 2000, 2001, 2003). Those studies make it clear that the provision of both piped water and sewage system connections for most households, increased investments in education and health and socioeconomic changes improving the living conditions of disadvantaged groups might lead to the permanent control of the disease.

In May 2001, all member nations of the World Health Organization (WHO) committed themselves with implementing an integrated strategy for prevention and control of schistosomiasis and soil-transmitted helminthiases (STH), through Resolution 54.19 of the World Health Assembly (WHA 54.19). The Assembly recognized that sanitation and safe-water supply are essential. It also reassured that the best measures to reduce morbidity and mortality as well as to improve health and development of the infected communities are the regular treatment of the high-risk groups, specially school-aged children, and the

${ }^{+}$Corresponding author: tfavre@ioc.fiocruz.br

Received 25 May 2006

Accepted 26 June 2006 access to drugs through the primary health care services. WHA 54.19 set the minimum target of treating at least $75 \%$ of all school-aged children from the endemic areas by year 2010 .

WHO made a partnership with international agencies, research and education institutions and non-governmental organizations (PPC 2002, WHO 2005a) to implement those recommendations. It also formed an Expert Committee to provide clear and strategic orientation on how to implement the recommendations (WHO 2002). A series of articles were published in internationally recognized periodicals systematizing the most recent technical and scientific information about the control of schistosomiasis and STH (Allen et al. 2002, Savioli et al. 2002, 2004 a, b, 2005, Crompton et al. 2003, Olds 2003, Richter 2003, Colley $\&$ Sear 2004).

The current strategies for schistosomiasis control recommended by the Ministry of Health (MoH) and the WHO are similar in various important aspects: (i) emphasis on preventive measures such as health education, safe-water supply, and sanitation; (ii) snail control only as an auxiliary measure; (iii) close interaction among the national, regional, and local levels of health organs; (iv) local availability of praziquantel for the cases diagnosed through the health services.

However, as regards diagnosis and treatment the two organs have different strategies. The $\mathrm{MoH}$ currently recommends (i) identification of infected persons through stool surveys carried out biennially by the municipal health organs in whole communities from the endemic areas and (ii) treatment of the diagnosed cases through the 
local health services (Funasa 1998). In contrast, the WHO proposes treatment targeted at high-risk groups (schoolaged children, adults with occupations requiring frequent contact with transmission foci) instead of whole communities.

As MoH's current guidelines were defined prior to resolution WHA 54.19, there is no specific orientation regarding the year 2010 minimum target for the endemic areas of schistosomiasis in Brazil. However, if whole community surveys followed by selective treatment are carried out at two-year intervals as recommended, the minimum target will be easily attained. Therefore, the issue is how effectively those recommendations have been implemented by the municipalities to meet the expectations.

The Rainforest Zone ("Zona da Mata") of Pernambuco (ZMP), also known as sugar-cane zone, remains one of the most concerned endemic areas of schistosomiasis in Brazil. It occupies $8456 \mathrm{~km}^{2}$ between coordinates $35^{\circ}-36^{\circ}$ $\mathrm{W}$ and $7^{\circ}-9^{\circ} \mathrm{S}$ enclosing 43 municipalities. According to the 2000 census (www.ibge.gov.br), the population totaled $1,207,324$ inhabitants $31 \%$ of which residing in rural areas. The school-aged population (7-14 yrs) added up to 205 thousand children, $17 \%$ of the total population. By 2004 , there were 187,742 children from that age range enrolled in 1415 schools of elementary education.

Between 1977 and 1996 the $\mathrm{MoH}$ accomplished four campaigns of diagnosis and treatment in the ZMP, covering an average of 39 municipalities per campaign (Favre et al. 2001). By the end of that period overall prevalence of infection by Schistosoma mansoni had dropped only 9.1 percentage points (pp), from 35.4 to $26.3 \%$. From 1996 to 1999 the MoH carried out its last campaign in that Zone, covering 40 municipalities. This enabled to identify five municipalities in the low prevalence class (less than 10\%) and 35 in the moderate prevalence class (between 10 and $50 \%$ ) according to WHO (2002) classification (Fig. 1).

By 1999 the Unified Health System (SUS) took over the Program for Schistosomiasis Control (PCE) in Pernambuco, making the municipalities responsible for the activities of diagnosis, treatment, and surveillance, as well as the definition of intervention priorities. In the ZMP the PCE-SUS was implemented only by 2001, with the goal of undertaking biennial surveys in all localities and treating the positive through the local health units.

The present work intends to evaluate whether the PCESUS (i) has followed the current guidelines of the $\mathrm{MoH}$ for schistosomiasis diagnosis and treatment by providing adequate population coverage and (ii) is able to attain the minimum target of resolution WHA 54.19 for year 2010 in the municipalities of the ZMP. Preventive, broader control measures such as health education, water supply and sanitation have not been systematically implemented by the PCE-SUS; therefore they will not be considered in this paper.

\section{METHODS}

The 2001-2004 annual reports from the Health Department of Pernambuco State (SES/PE) on schistosomiasis survey and treatment activities were used as source documents for the present work. The data were tabulated by micro-region (north, centre, and south), municipality, year, locality, population, number of persons examined, number of positives for S. mansoni, number of positives treated, number of non-treatment cases (refusal, absence, contra-indication).

The data were transferred to a statistical software (Systat 11) for calculating the following indices (Montresor et al. 2002) grouped by micro-region, municipality, year and locality: percentage of examined in the population, percentage of treated and percentage of no-treated due to refusal, absence or contra-indication. The data regarding prevalence of infection will be evaluated in a separate paper (Favre et al. 2006).

\section{RESULTS}

The SES/PE reported for year 2001 only 18,667 exams in five municipalities of the ZMP, with no information about the localities covered. Therefore, they will not be considered here. As regards the period from 2002 to 2004 there are data on 83,003 exams at the locality level, which will be considered as follows.

At four years after resolution WHA 54.19, 37 (86\%) out of 43 municipalities from ZMP had been attended by the PCE-SUS, leaving six of them without coverage. During the 2002-2004 period only 404 (14.8\%) of the 2732 existing localities were surveyed. Nine (20.9\%) municipalities in 2002, 17 (39.5\%) in 2003, and 36 (83.7\%) in 2004 had at least one locality covered. However, less than $10 \%$ of the existing localities were attended in 22 municipalities. The situation was particularly critical in four municipalities (Jaqueira, Sirinhaém, Vicência, Xexéu), where only one locality was covered over that period (Table I)

Percentages below $10 \%$ of persons examined occurred in seven (77.8\%) of nine municipalities attended in 2002, $11(64.7 \%)$ of 17 in 2003, and 33 (91.7\%) of 36 in 2004. Only three municipalities registered $25 \%$ or more persons examined over that period (Table II).

Only 77 localities were surveyed more than once from 2002 to 2004 . Five localities were surveyed yearly: the municipal centre of Belém de Maria (one out of 36 localities covered), the municipal centre of Lagoa do Carro (one out of 17 localities covered), Sítio Brasil and Sítio Lagoinha (two out of 20 localities covered in the municipality of Chã de Alegria), and Canto Escuro (one out of 28 localities covered in the municipality of Escada).

The municipalities with localities surveyed twice were: Aliança (two out of 20 covered), Barreiros (one out of 10), Belém de Maria (25 out of 36), Camutanga (one out of two), Catende (four out of 24), Chã de Alegria (11 out of 20), Chã Grande (six out of 15), Escada (four out of 28), Lagoa do Carro (11 out of 17), and Tracunhaém (two out of 31). In the municipalities of Condado, Itambé, Macaparana, Maraial, and Quipapá one locality was covered in two surveys. In the remaining 22 municipalities, there was only one survey in the localities covered (Fig. 2).

Table III shows that treatment coverage over $70 \%$ were obtained in eight out of nine municipalities attended in 2002,12 of 17 in 2003 and 25 of 36 in 2004. Both in 2002 and 2004 compliance was around $85 \%$. Over that period only $1,900(18.7 \%)$ out of 10,644 cases were left untreated. Among the reasons for non-treatment there were $62.1 \%$ 
absences, $35.3 \%$ contra-indications, and $2.6 \%$ refusal. In five out of seven occurrences in which compliance reached $100 \%$, the average number of infected persons was 7.2. That was the case with seven out of 11 localities covered in the municipality of Paudalho in 2004 and with 13 other localities in different municipalities.

\section{DISCUSSION}

The recommendation made by the $\mathrm{MoH}$ that all population from the endemic municipalities should be surveyed biennially for treatment is far from being accomplished in the ZMP. Firstly, the six municipalities not yet reached by the PCE-SUS have left unattended about 200 thousand
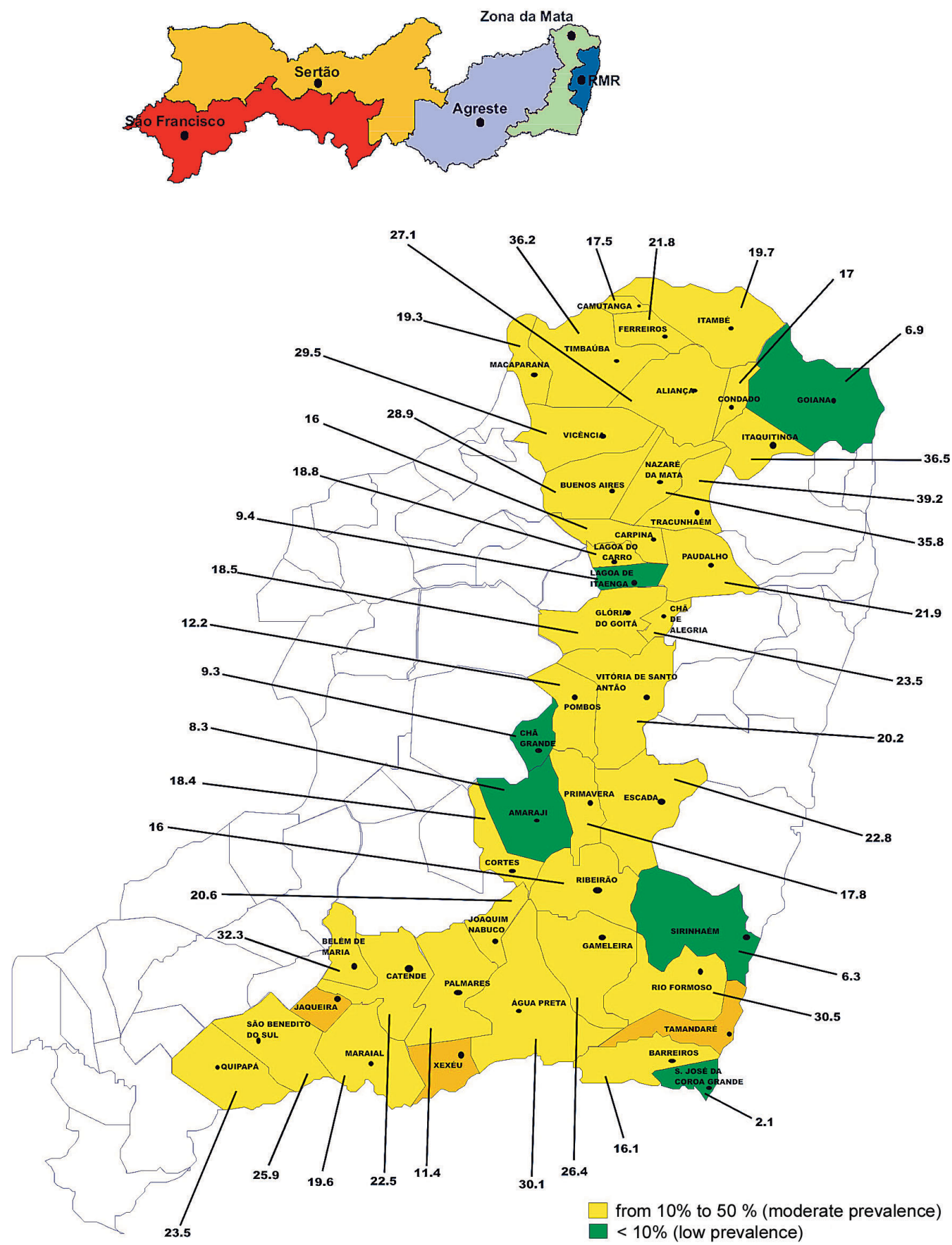

Fig. 1: prevalence (\%) of Schistosoma mansoni infection and prevalence classes for schistosomiasis in the municipalities of the Rainforest Zone ("Zona da Mata") of the state of Pernambuco according to the last campaign carried out by the Ministry of Health (1996-1999). Data kindly provided by Dr Ubiracy Guida from the National Health Foundation (Funasa). The municipalities of Jaqueira, Tamandaré, and Xexéu (dark yellow) were created after 1999. The five zones into which Pernambuco is divided are depicted in the small map. RMR: Recife Metropolitan Region. 
people under risk of infection. Secondly, only three municipalities achieved coverage of $25 \%$ or more in the 2002 2004 period. Assuming that any person was only examined once over that period, the total number of exams would not have exceeded $6.8 \%$ of the ZMP population. Considering that the school-aged children in the ZMP are $17 \%$ of the total population and taking into account that the PCE-SUS do not give priority to any age group, the surveys carried out from 2002 and 2004 would have at- tended 14 thousand school-aged children to the utmost. To accomplish the minimum target of year 2010 it is necessary to attend at least 154 thousand school-aged children ( $75 \%$ of the estimated total). This would require the examination of 461 thousand persons from all age groups, according to $\mathrm{MoH}$ recommendations.

As regards compliance to treatment, the relatively high percentages of absentee may be due to recently adopted guidelines for drug administration by the SES/PE. Before

TABLE I

Numbers of existing localities in the municipalities attended by the Schistosomiasis Control Program within United Health System (PCE-SUS), numbers and percentages (in parentheses) of localities covered from 2002 to 2004 in the Rainforest Zone of Pernambuco by micro-region (North, Centre, and South)

\begin{tabular}{|c|c|c|c|c|c|}
\hline & & & & vered localit & \\
\hline & Municipalities & Existing localities & 2002 & 2003 & 2004 \\
\hline North & Aliança & 136 & $7(5.1)$ & $2(1.5)$ & $13(9.5)$ \\
\hline & Buenos Aires & 59 & - & - & $2(3.4)$ \\
\hline & Camutanga & 9 & - & $1(11.1)$ & $2(22.2)$ \\
\hline & Carpina & - & - & - & - \\
\hline & Condado & 31 & - & $1(3.2)$ & $1(3.2)$ \\
\hline & Ferreiros & - & - & - & - \\
\hline & Goiana & 97 & - & - & $2(2.0)$ \\
\hline & Itambé & 58 & - & $1(1.7)$ & $1(1.7)$ \\
\hline & Itaquitinga & - & - & - & - \\
\hline & Lagoa Itaenga & 35 & - & - & $3(8.6)$ \\
\hline & Lagoa Carro & 30 & $3(10.0)$ & $15(50.0)$ & $12(40.0)$ \\
\hline & Macaparana & 81 & - & $1(1.2)$ & $2(2.5)$ \\
\hline & Nazaré da Mata & - & - & - & - \\
\hline & Paudalho & 88 & - & - & $11(12.5)$ \\
\hline & Timbaúba & - & - & - & - \\
\hline & Tracunháem & 60 & - & $30(50.0)$ & $2(3.3)$ \\
\hline & Vicência & 130 & - & - & $1(0.8)$ \\
\hline Centre & Chã de Alegria & 23 & $20(87.0)$ & $12(52.2)$ & $3(13.0)$ \\
\hline & Chã Grande & 53 & $4(7.5)$ & $6(11.3)$ & $11(20.7)$ \\
\hline & Glória Goitá & 99 & - & $30(30.3)$ & - \\
\hline & Pombos & - & - & - & - \\
\hline & Vitória S. Antão & 176 & - & - & $2(1.1)$ \\
\hline South & Água Preta & 155 & - & - & $3(1.9)$ \\
\hline & Amaraji & 62 & $1(1.6)$ & - & $1(1.6)$ \\
\hline & Barreiros & 70 & - & $5(7.1)$ & $6(8.6)$ \\
\hline & Belém Maria & 45 & $1(2.2)$ & $30(66.7)$ & $30(66.7)$ \\
\hline & Catende & 60 & $16(26.7)$ & $4(6.7)$ & $8(13.3)$ \\
\hline & Cortês & 33 & - & - & $3(9.0)$ \\
\hline & Escada & 104 & $11(10.6)$ & $12(11.5)$ & $11(10.6)$ \\
\hline & Gameleira & 50 & - & $10(20.0)$ & $7(14.0)$ \\
\hline & Jaqueira & 51 & - & - & $1(2.0)$ \\
\hline & Joaquim Nabuco & 41 & - & - & $2(4.9)$ \\
\hline & Maraial & 148 & - & $1(0.7)$ & $2(1.3)$ \\
\hline & Palmares & 127 & - & - & $1(0.8)$ \\
\hline & Primavera & 35 & - & - & $3(8.6)$ \\
\hline & Quipapá & 130 & $1(0.8)$ & - & $2(1.5)$ \\
\hline & Ribeirão & 69 & - & $1(1.4)$ & $11(15.9)$ \\
\hline & Rio Formoso & 104 & - & - & $3(2.9)$ \\
\hline & São B. do Sul & 72 & - & - & $9(12.5)$ \\
\hline & S. J.C.Grande & 27 & - & - & $2(7.4)$ \\
\hline & Sirinhaém & 92 & - & - & $1(1.1)$ \\
\hline & Tamandaré & 49 & - & - & $3(6.1)$ \\
\hline & Xexéu & 43 & - & - & $1(2.3)$ \\
\hline Total & & 2732 & $64(2.3)$ & $162(5.9)$ & $178(6.5)$ \\
\hline
\end{tabular}

—: municipalities not attended. 
the implementation of PCE-SUS, medication was carried out house to house by the health agents in charge of the stool surveys (Funasa 1998). As a result, the cases of absence were relatively few. At present, praziquantel can only be administered under medical prescription, requiring the attendance of the patient at a health centre. This usually involve many hours of travel and waiting, which may discourage compliance.

It is interesting to note that the cases of $100 \%$ compliance probably resulted from passive detection through the routine health services and not from active search by the PCE-SUS.

With regard to the relatively high percentages of nontreatment due to contra-indication, it should be of inter- est to evaluate whether the medical staff in charge of prescribing praziquantel in the local health units is unaware of the recent recommendations for the use of this drug. According to WHO (2003), praziquantel can be regarded as the safest among antihelminthic drugs. The risks during pregnancy and lactation are practically none, and all effort should be made to ensure the inclusion of the highly vulnerable group of pregnant and lactating women in any deworming program. The only contra-indication is hypersensitivity to the active component of the formula (Olds \& Dasarathy 2000).

If an evaluation of knowledge, attitude and practice (KAP) regarding praziquantel prescription would confirm the above hypothesis, the SES/PE could promote short-

\section{TABLE II}

Estimated population (www.ibge.gov.br), numbers and percentages (in parentheses) of persons examined from 2002 to 2004 in the municipalities attended by the Schistosomiasis Control Program within United Health System (PCE-SUS) in the Rainforest Zone of Pernambuco by micro-region (North, Centre, and South)

\begin{tabular}{|c|c|c|c|c|c|}
\hline & & & & as examined pe & \\
\hline & Municipalities & Population (2000 census) & 2002 & 2003 & 2004 \\
\hline North & Aliança & 37,188 & $2588(6.9)$ & $1559(4.2)$ & $1749(4.7)$ \\
\hline & Buenos Aires & 12,007 & - & - & $20(0.2)$ \\
\hline & Camutanga & 7830 & - & $118(1.5)$ & $539(6.9)$ \\
\hline & Condado & 21,756 & - & $789(3.6)$ & $1319(6.1)$ \\
\hline & Goiana & 71,088 & - & - & $3118(4.4)$ \\
\hline & Itambé & 34,966 & - & $2624(7.5)$ & $709(2.0)$ \\
\hline & Lagoa Itaenga & 19,908 & - & - & $641(3.2)$ \\
\hline & Lagoa Carro & 13,110 & $325(2.5)$ & $3114(23.7)$ & $1286(9.8)$ \\
\hline & Macaparana & 22,474 & - & $906(4.0)$ & $1049(4.7)$ \\
\hline & Paudalho & 45,063 & - & - & $1617(3.6)$ \\
\hline & Tracunháem & 12,379 & - & $3069(24.8)$ & $1852(15.0)$ \\
\hline & Vicência & 28,820 & - & - & $374(1.3)$ \\
\hline Centre & Chã de Alegria & 11,106 & $5739(51.7)$ & $1122(10.1)$ & $118(1.1)$ \\
\hline & Chã Grande & 18,403 & $538(2.9)$ & $534(2.9)$ & $1107(6.0)$ \\
\hline & Glória Goitá & 27,528 & - & $5080(18.4)$ & - \\
\hline & Vitória S. Antão & 121,269 & - & - & $323(0.3)$ \\
\hline South & Água Preta & 28,715 & - & - & $543(1.9)$ \\
\hline & Amaraji & 21,319 & $1(0.005)$ & - & $691(3.2)$ \\
\hline & Barreiros & 39,151 & - & $153(0.4)$ & $300(0.8)$ \\
\hline & Belém Maria & 10,634 & $1013(9.5)$ & $6038(56.8)$ & $3487(32.8)$ \\
\hline & Catende & 31,149 & $2654(8.5)$ & $3186(10.2)$ & $1926(6.2)$ \\
\hline & Cortês & 12,934 & - & - & $906(7.0)$ \\
\hline & Escada & 56,956 & $1085(1.9)$ & $1559(2.7)$ & $1290(2.3)$ \\
\hline & Gameleira & 23,784 & - & $554(2.3)$ & $1782(7.5)$ \\
\hline & Jaqueira & 11,653 & - & - & $637(5.5)$ \\
\hline & Joaquim Nabuco & 15,921 & - & - & $663(4.2)$ \\
\hline & Maraial & 13,940 & - & $126(0.9)$ & $652(4.7)$ \\
\hline & Palmares & 55,658 & - & - & $818(1.5)$ \\
\hline & Primavera & 11,470 & - & - & $441(3.8)$ \\
\hline & Quipapá & 22,202 & $2332(10.5)$ & - & $1480(6.6)$ \\
\hline & Ribeirão & 41,449 & - & $353(0.8)$ & $1316(3.2)$ \\
\hline & Rio Formoso & 20,763 & - & - & $703(3.4)$ \\
\hline & São B. do Sul & 10,477 & - & - & $845(8.1)$ \\
\hline & S. J.C.Grande & 13,927 & - & - & $116(0.8)$ \\
\hline & Sirinhaém & 33,079 & - & - & $157(0.5)$ \\
\hline & Tamandaré & 17,281 & - & - & $331(1.9)$ \\
\hline & Xexéu & 13,597 & - & - & $939(6.9)$ \\
\hline Total & & $1.010,954$ & $16,275(1.6)$ & $30,884(3.0)$ & $35,844(3.5)$ \\
\hline
\end{tabular}

-: municipalities not attended. 
term update courses based on a recent review about the drug aimed specifically at the clinical practice (Cioli \& Pica-Mattoccia 2003). A series of seminars on that subject has been carried out in 2002-2003 to doctors and nurses of the Family Health Program (PSF) from four municipalities in the Recife Metropolitan Region (Jaboatão, Itamaracá, Ipojuca, and Igarassu).

Reports on the PCE-SUS activities in other states of the endemic area of schistosomiasis in the Northeastern region indicate contrasting situations regarding the attendance of the recommended biennial goals by the $\mathrm{MoH}$. Thus, the Computerized System of the Schistosomiasis Control Program (SISPCE) (http://dtr2001.saude.gov.br/ svs/epi/esquis/esquis00.htm) records a total of $1.5 \mathrm{mil}-$ lion persons examined between 1997 and 2004 in Alagoas state, covering $53 \%$ of the population of 2.8 million according to the 2000 census (www.ibge.gov.br). For the state of Sergipe, however, the SISPCE informs that only $25 \%$ of the population was covered from 1996 to 2004.

Therefore, it is mandatory that the PCE-SUS identifies the problems involved in the nonattendance to its own goals and evaluates whether coverage can be improved within the capacity of the municipalities. It is possible that, in face of the context being experienced, the municipalities have already reached their maximum capacity, making it unfeasible to attend to any additional demand.

In the ZMP, the main limiting factors are probably the lack of material and human resources for the PCE-SUS activities at the municipal level as well as the overload of duties attributed to the local health services. In both cases, the PCE-SUS should give special attention to the most troubled municipalities and involve local educational organs as well as community associations to overcome the obstacles.

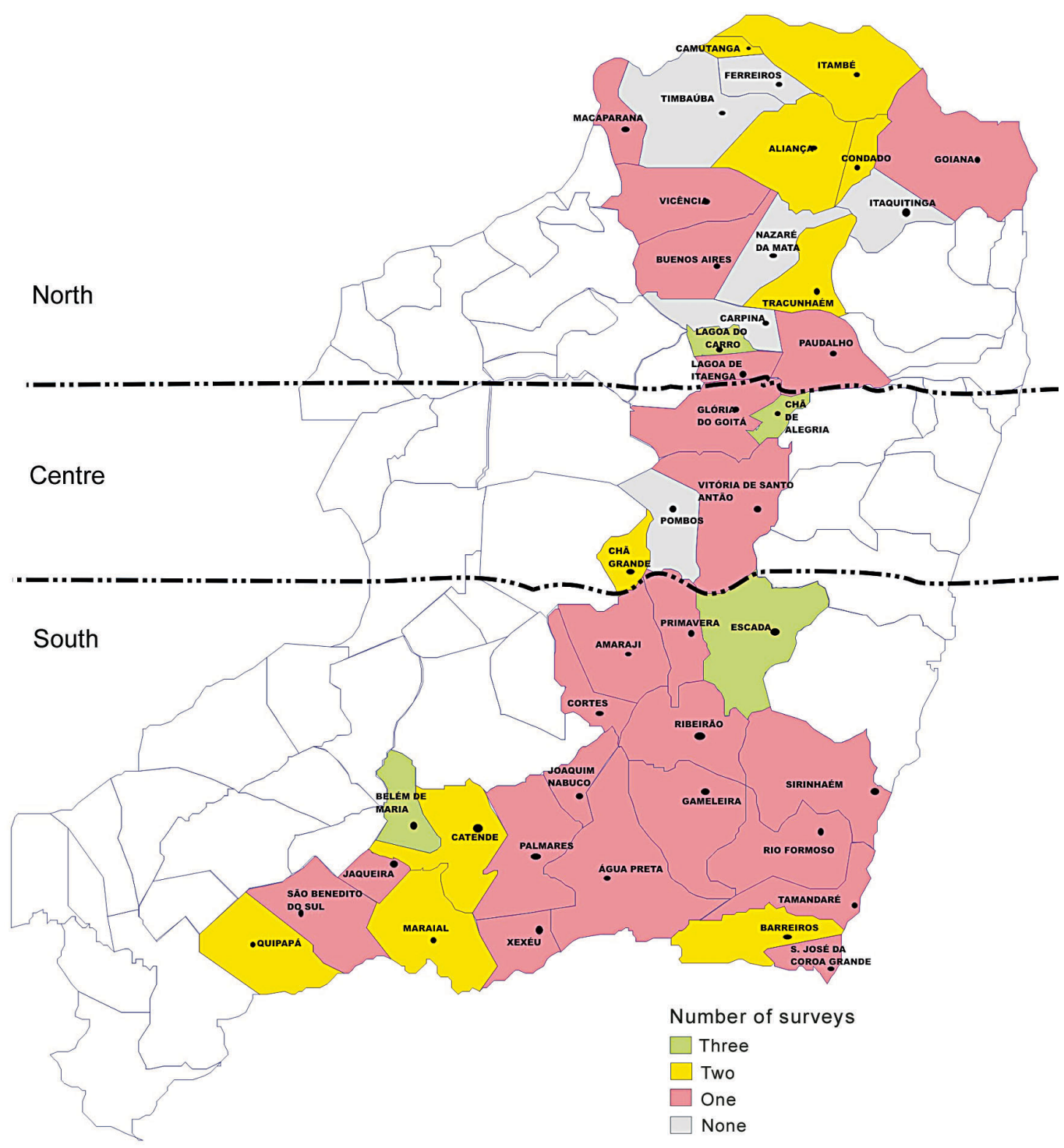

Fig. 2: number of surveys carried out by the Schistosomiasis Control Program within United Health System in the municipalities of the Rainforest Zone ("Zona da Mata") of Pernambuco from 2002 to 2004 . The micro-regions North, Centre, and South are also indicated. 
The following strategy may be recommended to start now for attaining the minimum target of resolution WHA 54.19 , based on the prevalence classes obtained in the last survey carried out by the MoH in 1996-1999 (Fig. 1) as well as the number of surveys carried out by the PCESUS in 2002-2004 (Fig. 2): (i) all six municipalities left unattended and 18 of those attended only once by the PCESUS had moderate prevalence. They should aim at undertaking stool surveys in all elementary schools and treating the infected school-aged children at a biennial basis. Even considering that school evasion in the ZMP may reach $35 \%$ (Condepe 2000), that scheme could provide coverage to 86,385 (65\%) out of 132,900 children aged 7-14 yrs living in those municipalities (year 2000 Census). The local educational and health organs could act together with the community associations to include non-enrolled school-aged children; (ii) the 19 municipalities attended more than once by the PCE-SUS should intensify diagnosis and treatment activities at the community level to increase coverage to at least $75 \%$ of the population; (iii) those municipalities remaining with prevalence above $10 \%$ should implement strategies of Information, Education and Communication (IEC) as well as sanitation and safe-water supply within the Integrated Covenanted Program for Epidemiology and Disease Control (PPI/ECD).

The above strategy should not be regarded as an intrusion on the municipal priorities, but as a contribution towards the attainment of the minimum target of resolution WHA 54.19 without compromising the PCE-SUS goals.

TABLE III

Coverage of treatment with praziquantel in the municipalities of the Rainforest Zone ("Zona da Mata") of Pernambuco attended by the Schistosomiasis Control Program within United Health System (PCE-SUS) from 2002 to 2004

\begin{tabular}{|c|c|c|c|c|c|c|}
\hline \multirow[b]{2}{*}{ Municipalities } & \multicolumn{2}{|c|}{2002} & \multicolumn{2}{|c|}{2003} & \multicolumn{2}{|c|}{2004} \\
\hline & Persons to treat & Treated $(\%)$ & Persons to treat & Treated $(\%)$ & Persons to treat & Treated (\%) \\
\hline Aliança & 212 & 75.5 & 337 & 75.4 & 458 & 67.2 \\
\hline Buenos Aires & - & - & - & - & 8 & 0 \\
\hline Camutanga & - & - & 3 & 100 & 11 & 63.6 \\
\hline Condado & - & - & 104 & 95.2 & 231 & 90.5 \\
\hline Goiana & - & - & - & - & 378 & 85.2 \\
\hline Itambé & - & - & 373 & 76.4 & 77 & 100 \\
\hline Lagoa de Itaenga & - & - & - & - & 37 & 10.8 \\
\hline Lagoa do Carro & 11 & 100 & 299 & 78.3 & 134 & 64.9 \\
\hline Macaparana & - & - & 51 & 68.6 & 57 & 47.4 \\
\hline Paudalho & - & - & - & - & 468 & 86.3 \\
\hline Tracunháem & - & - & 531 & 68.4 & 80 & 56.3 \\
\hline Vicência & - & - & - & - & 95 & 92.6 \\
\hline Chã de Alegria & 560 & 79.3 & 116 & 71.6 & 7 & 57.1 \\
\hline Chã Grande & 21 & 71.4 & 16 & 100 & 4 & 100 \\
\hline Glória de Goitá & - & - & 459 & 46.2 & - & - \\
\hline Vitória Santo Antão & - & - & - & - & 44 & 90.9 \\
\hline Água Preta & - & - & - & - & 73 & 100 \\
\hline Amaraji & 2 & 50.0 & - & - & 86 & 80.2 \\
\hline Barreiros & - & - & 53 & 92.5 & 16 & 56.3 \\
\hline Belém Maria & 146 & 95.9 & 721 & 99.9 & 393 & 93.6 \\
\hline Catende & 346 & 95.4 & 272 & 93.4 & 88 & 96.6 \\
\hline Cortês & - & - & - & - & 116 & 99.1 \\
\hline Escada & 400 & 86.5 & 674 & 78.5 & 280 & 71.1 \\
\hline Gameleira & - & - & 280 & 50.0 & 252 & 86.5 \\
\hline Jaqueira & - & - & - & - & 85 & 91.8 \\
\hline Joaquim Nabuco & - & - & - & - & 80 & 93.8 \\
\hline Maraial & - & - & 20 & 95.0 & 104 & 90.4 \\
\hline Palmares & - & - & - & - & 54 & 94.4 \\
\hline Primavera & - & - & - & - & 31 & 93.5 \\
\hline Quipapá & 147 & 85.7 & - & - & 62 & 96.8 \\
\hline Ribeirão & - & - & 52 & 69.2 & 110 & 95.5 \\
\hline Rio Formoso & - & - & - & - & 350 & 98.6 \\
\hline São B.do Sul & - & - & - & - & 84 & 90.5 \\
\hline São J.C. Grande & - & - & - & - & 0 & 0 \\
\hline Sirinhaém & - & - & - & - & 2 & 100 \\
\hline Tamandaré & - & - & - & - & 33 & 72.7 \\
\hline Xexéu & - & - & - & - & 50 & 98.0 \\
\hline Total & 1845 & 85.3 & 4361 & 76.4 & 4435 & 84.5 \\
\hline
\end{tabular}

—: municipalities not attended. 


\section{ACKNOWLEDGEMENTS}

To Dr Ubiracy Guida (in memoriam), from the National Health Foundation, for kindly providing the prevalence data of the 1996-1999 survey.

\section{REFERENCES}

Allen HE, Crompton WT, de Silva N, LoVerde PT, Olds GR 2002. New policies for using anthelmintics in high risks groups. Trends Parasitol 18: 381-382.

Barbosa CS, Barbosa FS 1998. Padrão epidemiológico da esquistossomose em comunidade de pequenos produtores rurais de Pernambuco, Brasil. Cad Saúde Públ 14: 129-137.

Cioli D, Pica-Mattoccia L 2003. Praziquantel. Parasitol Res 90 : S3-S9

Colley DG, Sear WE 2004. Immunoregulation and World Health Assembly resolution 54.19: why does treatment control morbidity? Parasitol Internal 53: 143-150.

Condepe 2000. Mesorregião da Mata Pernambucana: Microrregião da Mata Setentrional, da Mata Meridional e de Vitória de Santo Antão. Monografia Mesorregional. Instituto de Planejamento de Pernambuco, Recife, 120 pp.

Crompton DWT, Engels D, Montresor A, Neira MP, Savioli L 2003. Action starts now to control disease due to schistosomiasis and soil-transmitted heminthiasis. Acta Trop 86: 121-124.

Coura JR, Amaral RS 2004. Epidemiological and control aspects of schistosomiasis in brazilian endemic areas. $\mathrm{Mem}$ Inst Oswaldo Cruz 99 (Suppl. 1): 13-19.

Engels D, Chitsulo L, Montresor A, Savioli L 2002. The global epidemiological situation of schistosomiasis and new approaches to control and research. Acta Trop 82: 139-146.

Favre TC, Pieri OS, Barbosa CS, Beck L 2001. Avaliação das ações de controle da esquistossomose implementadas entre 1977 e 1996 na área endêmica de Pernambuco, Brasil. Rev Soc Bras Med Trop 34: 569-576.

Favre TC, Ximenes AAR, Galvão AF, Pereira APB Wanderley TN, Barbosa CS, Pieri OS 2006. Reliability of current estimates of schistosomiasis prevalence in the Rainforest Zone of the state of Pernambuco, Northeastern Brazil. Mem Inst Oswaldo Cruz 101 (Suppl. I): in press.

Freese de Carvalho EMF, Acioli MD, Branco MAF, Costa AM, Cesse EAP, Andrade AG, Mello EMLL 1998. Evolução da esquistossomose na zona da mata sul de Pernambuco. Epidemiologia e situação atual: controle ou descontrole? Cad Saúde Pub 14: 787-795.

Funasa 1998. Controle da Esquistossomose. Diretrizes Técnicas, 2nd ed., Brasília, 70 pp.

Moza PG., Pieri OS, Barbosa CS, Rey L 1998. Fatores sócio- demográficos e comportamentais relacionados à esquistossomose em uma agrovila da zona canavieira de Pernambuco, Brasil. Cad Saúde Públ 14: 107- 115.

Montresor A, Crompton D, Gyorkos TW, Saviolli L 2002. Helminth Control in School-age Children: A Guide for Managers of Control Programmes, World Health Organization, Geneva, $73 \mathrm{pp}$.

Olds GR 2003. Administration of praziquantel to pregnant and lactating women. Acta Trop 86: 185-195.

Olds GR, Dasarathy 2000.Current Treatment Options in Infectious Diseases 2:88-99

PPC 2002. The partnership for Parasite Control (PPC). The Second Meeting - Rome- 25-26 April 2002. www.who.int/ entity/wormcontrol/about_us/en/mtgnotes-april2002.pdf (acess 19/9/2005).

Richter J 2003 The impact of chemotherapy on morbidity due to schistosomiasis. Acta Trop 86: 161-183.

Savioli L, Albonico M, Engels, Montresor A 2004a. Progress in the prevention and control of schistosomiasis and soil-transmitted helminthiasis. Parasitol Internal 53: 103-113.

Savioli L, Engels D, Roungou JB, Fenwick A, Endo H 2004b. Schistosomiasis control. Lancet 363: 658.

Savioli L, Engels D, Endo H 2005. Extending the benefits of deworming for development. Lancet 365: 1520-1521.

Savioli L, Stansfield S, Bundy DAP 2002. Schistosomiasis and soil-transmitted helminth infections: forging control efforts. Trans $R$ Soc Trop Med Hyg 96: 577-579.

WHO 2002. Prevention and control of schistosomiasis and the soil-transmitted helminthiasis. Report of a WHO Expert Committee, World Health Organization, Geneva, 73 pp.

WHO 2003. Essential medicines. WHO Drug Information 17: 29-31.

WHO 2005. Report of the third global meeting of the partners for parasite control. Deworming for Health and Development. WHO/CDS/CPE/PVC/2005.14, 51 pp.

Ximenes RAA, Southgate B, Smith, PG, Guimarães-Neto L 2000. Migration and urban schistosomiasis. The case of São Lourenço da Mata, Northeast of Brazil. Rev Inst Med Trop São Paulo 24: 209-217.

Ximenes RAA, Southgate B, Smith PG, Guimarães-Neto L 2001. Social environment, behavior, and schistosomiasis in the Northeast of Brazil. Pan Am J Public Health 9: 13-22.

Ximenes RAA, Southgate B, Smith PG, Guimarães-Neto L 2003. Socioeconomic determinants of schistosomiasis in na urban área in the Northeast of Brazil. Pan Am J Public Health 14: 409-421. 